Brit. J. prev. soc. Med. (1965), 19, 69-79

\title{
CHILDHOOD PARENT-LOSS IN A PSYCHIATRICALLY
}

\author{
NORMAL POPULATION
}

\author{
BY \\ ALISTAIR MUNRO \\ From the Medical Research Council Unit for Research on the Epidemiology of Psychiatric Illness, \\ University of Edinburgh
}

There is a good deal of theoretical speculation in the psychiatric literature regarding the aetiological significance of childhood parent-loss in mental illness. Some of the speculation is undoubtedly based on a lack of appreciation of the extent to which childhood parental bereavement occurs in the general population. This article reports on a study which investigates childhood parent-loss in a group of individuals who have no history of serious psychiatric disorder, and the results suggest that parental bereavement in childhood may normally be a much commoner event than is generally supposed.

There is another aim underlying the article. The data to be discussed were obtained from 210 outpatients attending medical and surgical clinics in a general hospital and it will be demonstrated that these out-patients appear to be a suitable source of normal data on parental bereavement.

\section{Childhood Parent-Loss and Psychiatric DISORDER}

In this article the main emphasis is on actual physical separation of parent and child, both permanent and temporary. Separation of a child from its parents need not necessarily induce a sense of deprivation; to take an extreme case, the death of a brutal parent may actually improve the child's lot. However, it is a matter of common experience that most young children become noticeably upset when their parents are absent for an unduly long time. Bowlby (1962) has given a graphic account of the reaction of children admitted to hospital or residential nursery and defines three stages into which this reaction may fall. In the last stage, that of detachment, the child may no longer recognize the parent. This can be viewed as a normal adaptive mechanism, enabling a child to form a close relationship with a parent-substitute without being handicapped by unnecessary grieving over a lost loveobject. What Bowlby perhaps fails to stress sufficiently is that, if conditions are favourable and the child is able to relate meaningfully to some adult, the period of distress following separation from the parents should be short-lived and should give rise to no untoward effects. If, on the other hand, the child is given no opportunity to form a satisfying emotional relationship, distress may be prolonged and profound.

Bowlby and many others believe that it is the separation-experience itself that is traumatic and separation from the mother is usually held to be of greater importance. The reaction to this is regarded as a form of mourning which, in some cases, may be pathologically prolonged to form the basis of a psychological disorder which becomes manifest in adult life. Unfortunately, as Casler (1961) points out, many of the earlier studies which seemed to confirm these ideas were carried out in institutions where there was no appreciation of the emotional needs of young children. Infants might be raised in conditions of impeccable hygiene but to attain these conditions they were forced to lead an isolated and almost stimulus-free existence. Little wonder that various workers, for example Bowlby (1940, 1944), Ribble (1943), and Spitz (1945), could describe the children in these institutions as apathetic, lacking in concentration, and incapable of forming stable emotional relationships. However, later studies, for example those by Rheingold (1956) and Rheingold and Bayley (1959), fail to demonstrate undue psychological disturbance in institutionalized children, which may perhaps reflect the increasingly humane attitude of institutions towards the children in their care.

Although the original hypothesis of a relationship between separation from the parents and subsequent mental illness has perhaps been weakened by recent findings, many psychiatrists still believe that the separation-experience per se is an important aetiological factor in various disorders. Bowlby (1962) states that parentally deprived individuals are 
especially liable to delinquent character formation and personality prone to anxiety states and depression. Other workers have claimed to find a significant connexion between parental deprivation and, for example, psychoneurosis (Stengel, 1943; Madow and Hardy, 1947; Ingham, 1949; Barry and Lindemann, 1960), suicide and attempted suicide (Palmer, 1941; Reitman, 1942; Simon, 1950; Batchelor and Napier, 1953; Robins, Schmidt, and O'Neal, 1957), schizophrenia (Wahl, 1956; Lidz and Lidz, 1949; Oltman, McGarry, and Friedman, 1951; Hilgard and Newman, 1963) and depressive illness (Brown, 1961; Beck, Sethi, and Tuthill, 1963).

These findings may be correct but, if so, parental deprivation seems a remarkably non-specific predisposing factor; moreover to demonstrate a relationship is not necessarily to prove that it is an aetiological one. However, the accuracy of the results of many of the studies just quoted is considerably in doubt, mainly because of methodological faults. Terms are often ill-defined, series small, and control material poorly matched or completely absent. In fact, it can be said that, while these studies provide fascinating hints, no one has as yet satisfactorily demonstrated a significant aetiological connexion between parental bereavement and mental illness.

\section{Methods of Studying Parental Bereavement}

Much of the writing on parental bereavement in the psychoanalytic literature is on an intuitive level and is based on experience of a small number of cases. The only satisfactory method of examining the predisposing effects of bereavement in both the short and the long term, would be to conduct a lifelong study, comparing large, closely matched cohorts of parentally deprived and non-deprived individuals and observing whether significantly different patterns of psychiatric morbidity emerged in the two groups. Since this type of ongoing investigation involves great problems of time and resources, retrospective studies are almost invariably used to observe the effects of parental bereavement.

Usually, a group of patients suffering from some psychiatric disorder is compared with normals to observe whether the former have suffered excessively from parent-loss in childhood. Occasionally (Earle and Earle, 1961 ; Imboden, Canter, and Cluff, 1963), a group of parentally deprived individuals is compared with non-deprived controls to discover if the deprived group shows an increased tendency to psychiatric disorder. This method is less popular because it is more difficult to gather a group of the parentally deprived than a group of psychiatric patients.

In such studies, an attempt is made to demonstrate that mental illness is associated with a higher-thannormal rate of parental loss in childhood. Yet we apparently do not know the normal level of parental loss in the general population. As Gregory (1958) points out, there is probably no absolute value, because the frequency of parental bereavement may vary widely according to time and place, to prevailing rates of morbidity and mortality, and to the amount of separation and divorce in the community. $\mathrm{He}$ also emphasizes that fathers are almost always absent from the childhood home to a greater extent than mothers because men are usually older than their wives, males have a higher death rate than females of the same age, and it is usually father who disappears in circumstances such as war or divorce. All these variables must be carefully controlled in a study.

If childhood parent-loss in the community is subject to so many influences it may be futile to attempt to define a normal level for it or even to set normal limits of variation. The present study does provide a "normal" value but this need not necessarily apply to other communities, times, or circumstances. On the other hand, a knowledge of how high the level may be in the general population may temper the enthusiasm of those who consider parental bereavement to be invariably a serious and traumatic event and, of course, the greater the number of normal values which become available, the greater will be the confidence with which values outside their range may be declared abnormal.

\section{Definition OF TeRMS}

As already indicated, many studies fail to define their terms accurately and so it may be difficult to know exactly what aspect of parental bereavement is under consideration. Since by convention the death of a parent is regarded as a serious loss to the child (and since it is also the most easily verified form of parent-loss) it is often taken as the index of parental bereavement. But because prolonged absence of a parent may be just as upsetting to a child, in some studies, absences lasting more than an arbitrary length of time are included in the definition of bereavement. Sometimes, a vaguer concept of bereavement such as "the broken home" is employed and unless it is known exactly what such a term implies, comparison between studies is made almost impossible. To increase the difficulties further, there is no widely held agreement as to the length of childhood and authors are forced to set their own 
arbitrary limits to the period, again reducing the comparability of the results.

The terms used in this study are now defined for the sake of clarity:

(1) Parental bereavement

(2) Parental loss

(3) Parental deprivation $\int$ and child for any cause.

(4) Parental absence: this term denotes loss of a parent for a cause other than death. Only absence lasting more than three months at a time is included.

(5) Disturbed relationship with a parent: this term is used where an individual has reported that, during part of childhood at least, relations with a parent-figure were consistently strained or unhappy.

(6) Childhood is defined as the period from birth till the 16th birthday.

\section{Previous Studies on Parental Bereavement in} Normal PopUlations

Much of the interest in childhood parental bereavement is due to its supposed relationship with psychiatric disorder and delinquency, and apart from actuarial purposes there seems to have been little incentive to study its frequency in normal populations. Those psychiatric studies which provide normal data often rely on quite seriously biased control populations the suitability of which is in considerable doubt. Table I shows the results of six studies on parental death. Apart from the statistics of the Metropolitan Life Insurance Company (1944), the results have been obtained from the control series of studies investigating parental deprivation in various psychiatric illnesses.
Three of these investigations have agreed on the 15th birthday as the upper age limit of childhood but the remainder have set successively higher age limits. Of the psychiatric studies, only that of Hilgard, Newman, and Fisk (1960) is a true general population study, and it is noteworthy that it records the highest frequency of parent-loss, even allowing for the longer period of childhood. It would seem reasonable to assume that the figures obtained in general practice (Brown, 1961) and those from general hospital in-patients (Norton, 1952) would be more or less representative of the general population and indeed they agree fairly closely with each other and with those of Hilgard and others (1960). They suggest that, very approximately, in the population at large, at least 1 per cent. of parents die during each year of childhood and adolescence of the offspring.

There are apparently very few studies which report objectively on parental deprivation due to causes other than death occurring in the early lives of normal individuals. Unfortunately, the criteria used to define separation are so variable and at times, so subjective, as to render available studies difficult of interpretation. For example, Stein and Sklaroff (1957) reported that, in a stable residential district of Edinburgh, 16 per cent. of families with children of school age existed as broken homes. Oltman and others (1951), studying a group of hospital employees, estimated that approximately 30 per cent. of their subjects had suffered a deprivation experience before the 19th birthday. Imboden and others (1963), using a very wide definition of separation experience, found that 25 per cent. of a group of healthy, employed adults had suffered such an experience at some time in their lives. As can be seen, these studies provide little indication of the actual amount of parent-child separation which can normally be expected to occur but they do suggest that it is considerable.

TABLE I

INCIDENCE OF LOSS OF A PARENT BY DEATH DURING EARLY LIFE

\begin{tabular}{|c|c|c|c|c|c|c|c|c|c|}
\hline \multicolumn{6}{|c|}{ Author } & \multirow{2}{*}{$\begin{array}{c}\text { Date } \\
\text { (1952) }\end{array}$} & \multirow{2}{*}{$\begin{array}{c}\text { Observed Population } \\
\text { General Hospital In-patients }\end{array}$} & \multirow{2}{*}{$\begin{array}{c}\begin{array}{c}\text { Upper Age Limit } \\
\text { to Early Life }\end{array} \\
\text { 15th Birthday }\end{array}$} & \multirow{2}{*}{$\begin{array}{c}\begin{array}{c}\text { Percentage who } \\
\text { have lost a } \\
\text { Parent by Death } \\
\text { in Early Life }\end{array} \\
14 \cdot 2\end{array}$} \\
\hline Norton & .. & . & .. & . & .. & & & & \\
\hline Wahl & .. & 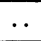 & . & $\ldots$ & .. & (1956) & US Naval Recruits & 15th Birthday & $11 \cdot 4$ \\
\hline Brown & .. & . & .. & . & .. & (1961) & General Practice Patients & 15th Birthday & $15 \cdot 5$ \\
\hline Brown & .. & $\ldots$ & .. & $\ldots$ & $\ldots$ & (1961) & Figures from 1921 Census & 15th Birthday & $11 \cdot 9$ \\
\hline \multicolumn{6}{|c|}{ Metropolitan Life Insurance Company } & (1944) & General Population & 18th Birthday & $16 \cdot 7$ \\
\hline Hilgard & .. & .. & .. & . & .. & (1960) & General Population & 19th Birthday & 21 \\
\hline \multicolumn{4}{|c|}{ Ingham, Newman, and Fisk } & $\ldots$ & $\ldots$ & (1949) & University Students & 22nd Birthday & $19 \cdot 2$ \\
\hline
\end{tabular}


Obviously, the majority of individuals who lose a parent in childhood attain psychological maturity despite this, and this awkward fact cannot satisfactorily be explained away by those who see the actual loss of the parent as an important predisposing factor in mental illness. If, as seems likely, separation from the parents is a good deal commoner than is usually realized, its aetiological significance may be regarded with some reservation.

\section{The INVESTIGATION}

An important aim of this study is to demonstrate that medical and surgical out-patients together form a suitable source of normal data on parental deprivation. As is well known, it is extremely difficult in practice to obtain an unbiased sample of the general population (Swaroop, 1960), but it seemed possible that non-psychiatric out-patients attending a large general hospital might serve the purpose. A hospital serving a fairly densely populated area has a substantial out-patient turn-over and most levels of the community are represented in the out-patient ranks. On the whole, out-patients are probably less highly selected than in-patients and general clinics are likely to deal with a less biased group of individuals than the more specialized clinics.

Fortunately, the out-patients who were investigated in this study proved eminently suitable in providing normal data. A questionnaire was devised and each out-patient was interviewed by the author, using the questionnaire as the basis of a standard interview. During interview, the patient's mental state was assessed and an inquiry was made into previous mental health. Patients attending six different clinics were investigated (three clinics in general medicine, two in general surgery, and one in orthopaedic surgery) to counteract the influence of undue selection which might apply to a particular clinic. Only out-patients attending by appointment were seen as it seemed unfair to subject emergency cases to an apparently irrelevant interview and, since the study was concerned with parental bereavement in childhood, only patients of 16 years and above were interviewed.

Since it was not possible, because of lack of appropriate data relating to the community at large, to assess directly the out-patients' comparability with the general public, the following method was employed to demonstrate their representativeness. When data collection was complete, a statistical comparison by the $\chi^{2}$ method was made between the medical and surgical out-patients and between the male and female patients on fourteen socio-demographic factors chosen beforehand as being apposite to the study (see below). It was reasoned that, if many significant differences arose between these sub-groups, it would suggest that a good deal of bias had entered into their selection. On the other hand, if few or no significant differences became apparent it would either have to be assumed that all the sub-groups differed from the general population in the same way and in a considerable number of respects, which seems unlikely; or else the entire group of out-patients would appear to be internally consistent and probably not too unrepresentative of the public at large. As will be shown, no significant differences were found.

\section{Method OF InVESTIGATION}

Permission was obtained by the author to attend six out-patient clinics at the Western General Hospital, Edinburgh, a general hospital of 510 beds with a very active out-patient department. The consultants in charge of each clinic agreed that patients could be interviewed when their consultation was at an end, but as it was impossible to see every patient at a busy clinic the following procedure was adopted: the first patient to become available was interviewed and thereafter the first patient to finish consultation after each interview had been completed. Intervening patients were allowed to leave without being seen and by this means the rhythm of the clinic was not disturbed and, if anything, the randomness of the patient sample was enhanced. It had previously been decided that about 200 out-patients would suffice for the series and data collection was stopped at the end of the week in which the 200th patient was seen. Of 223 individuals asked to participate, only one, a woman attending the orthopaedic clinic, refused.

As the group was to be as nearly as possible a psychiatrically normal one, it was necessary that it should contain no individuals with a history of psychotic illness. Any out-patients who gave a history suggestive of psychosis were therefore rejected from the series. Twelve patients were withdrawn on this account, all of whom gave a history suggestive of affective disorder. No other psychoses were found to be represented (see Table II).

TABLE II

SUBJECTS WITHDRAWN FROM THE SERIES BECAUSE OF A POSSIBLE HISTORY OF AFFECTIVE DISORDER

\begin{tabular}{|c|c|c|}
\hline History & & No. of Cases \\
\hline 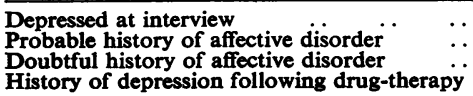 & $\begin{array}{l}\cdots \\
\cdots \\
\cdots\end{array}$ & $\left.\begin{array}{l}2 \\
3 \\
5 \\
2\end{array}\right\} 12$ \\
\hline
\end{tabular}


No further selection was made and the data presented hereafter refer to the remaining 210 outpatients. Their sub-division according to sex and clinical status is shown in Table III, orthopaedic patients being included in the surgical group.

\section{TABLE III}

DISTRIBUTION OF OUT-PATIENT SUBJECTS INTO SUB-

\begin{tabular}{|c|c|c|c|c|}
\hline Sex & .. & Male & Female & Total \\
\hline \multirow{2}{*}{$\underset{\text { Status }}{\text { Clinical }}$} & $\begin{array}{l}\text { Medical } \\
\text { Surgical }\end{array}$ & $\begin{array}{l}48 \\
44\end{array}$ & $\begin{array}{l}69 \\
49\end{array}$ & $\begin{array}{r}117 \\
93\end{array}$ \\
\hline & Total .. & 92 & 118 & 210 \\
\hline
\end{tabular}

The great majority of the out-patients come from a fairly circumscribed geographical area, only eleven ( $5 \cdot 2$ per cent.) living outside Edinburgh, Midlothian, or West Lothian. The age range of the sample is 16 to 79 years (mean $49 \cdot 34$ ). As might be expected, there is a marked preponderance of the middle-aged in the sample; this is best seen in the Figure, where the age distribution of the male and female out-patients is compared with that of the inhabitants of Edinburgh. GROUPS, ACCORDING TO SEX AND CLINICAL STATUS

Because of the excess of middle-aged individuals, there is a seeming excess of the married among the out-patients as compared with the population of Edinburgh. This mainly signifies that the general population contains a large number of young people who have not yet reached the age of marriage (Table IV).

\section{Testing the Internal Consistency of THE OUT-PATIENT SAMPLE}

It has already been explained that fourteen sociodemographic factors were chosen in advance in order to test the sub-groups into which the sample was divided:

1. Age distribution.

2. Civil status.

3. Socio-economic status (as measured by the Registrar General's five social classes).

4. Religion.

5. Death of a parent before the 16th birthday.

6. Absence of a parent for a cause other than death for a period of at least 3 months, before the 16th birthday.

7. Complaint by the patient of a disturbed relationship with a parent during childhood.

GENERAL HOSPITAL OUT-PATIENTS PRESENT STUDY
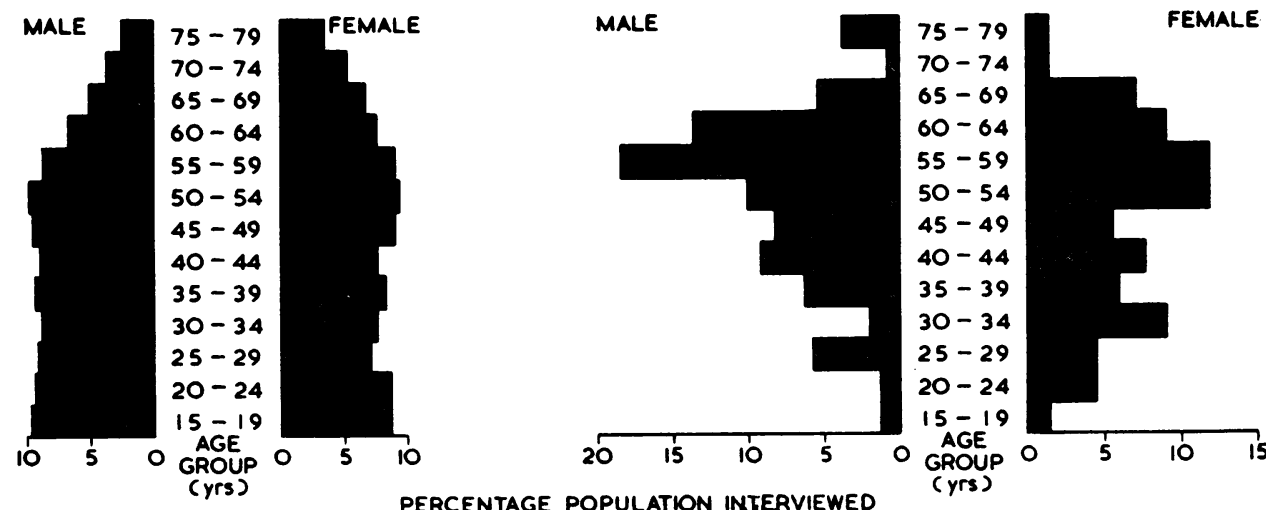

PERCENTAGE POPULATION INTERVIEWED

FIGURE-Sex and age distribution of the population of the city of Edinburgh and of the General Hospital Out-patient subjects.

TABLE IV

CIVIL STATUS OF OUT-PATIENT SUBJECTS COMPARED WITH MEMBERS OF EDINBURGH POPULATION AGED 15 YEARS AND OVER, BY SEX

\begin{tabular}{|c|c|c|c|c|c|c|c|c|c|c|}
\hline \multirow{2}{*}{$\frac{\text { Sex }}{\text { Series }}$} & \multirow{2}{*}{$\cdots$} & \multirow{2}{*}{$\cdots$} & \multirow{2}{*}{$\cdots$} & \multirow{2}{*}{$\cdots$} & \multirow{2}{*}{$\frac{\cdots}{\cdots}$} & \multirow{2}{*}{$\cdots$} & \multicolumn{2}{|c|}{ Male } & \multicolumn{2}{|c|}{ Female } \\
\hline & & & & & & & Out-patients & $\begin{array}{l}\text { Edinburgh } \\
\text { Population* }\end{array}$ & Out-patients & $\begin{array}{l}\text { Edinburgh } \\
\text { Population }\end{array}$ \\
\hline \multirow{2}{*}{\multicolumn{3}{|c|}{ Civil Status (per cent.) }} & & $\begin{array}{l}\text { Single } \\
\text { Married } \\
\text { Widowed } \\
\text { Divorced. }\end{array}$ & $\ddot{x}$ & $\begin{array}{l}\ddot{ } \\
\ddot{*}\end{array}$ & $\begin{array}{c}10 \cdot 9 \\
79 \cdot 3 \\
9 \cdot 8 \\
-\end{array}$ & $\begin{array}{r}27 \cdot 1 \\
67 \cdot 8 \\
4 \cdot 5 \\
0 \cdot 6\end{array}$ & $\begin{array}{r}11 \cdot 9 \\
72.9 \\
13.6 \\
1.7\end{array}$ & $\begin{array}{r}28 \cdot 4 \\
56 \cdot 2 \\
14 \cdot 4 \\
1 \cdot 1\end{array}$ \\
\hline & & & & Total & $\ldots$ & .. & 100 & 100 & 100 & 100 \\
\hline
\end{tabular}

* Figures obtained from the 1961 Census. 
8. Size of the sibship in the patient's family of upbringing.

9. Number of children in the patient's own family.

10. Presence of a family history of mental disorder.

11. Age of father at subjects' birth.

12. Age of mother at subject's birth.

13. Age at time of father's death.

14. Age at time of mother's death.

Only the first seven of these factors are considered in this article as the remainder are irrelevant to the present topic. It suffices to say that no significant differences were noted between sub-groups when Factors 8 to 14 were examined.
Table $\mathrm{V}$ compares the sub-groups by age, civil status, socio-economic status, and religion (Factors 1-4). No significant differences are seen, and it seems likely that in these respects the out-patients are fairly typical of the local population, which is essentially stable, Social Class III, and Protestant.

In Table VI the sub-groups are compared according to frequency of parental death and parental absence in childhood (Factors 5 and 6); no significant differences are apparent.

Table VII (opposite) shows the frequency with which the subjects complained of a disturbed relationship with a parent-figure in childhood (Factor 7); there are no significant differences between the sub-groups.

TABLE $\mathrm{V}$

COMPARISON OF OUT-PATIENT SUB-GROUPS BY AGE, CIVIL STATUS, SOCIAL CLASS, AND RELIGION

\begin{tabular}{|c|c|c|c|c|c|c|c|c|c|c|c|c|c|c|c|c|}
\hline \multirow{3}{*}{ Out-patient } & \multirow{3}{*}{ o-Groups } & \multirow{3}{*}{. } & \multirow{3}{*}{. } & \multirow{3}{*}{. } & \multicolumn{6}{|c|}{ Medical : Surgical } & \multicolumn{6}{|c|}{ Male : Female } \\
\hline & & & & & \multicolumn{2}{|c|}{ Medical } & \multicolumn{2}{|c|}{ Surgical } & \multirow{2}{*}{$x^{2}$} & \multirow{2}{*}{$\mathbf{P}$} & \multicolumn{2}{|c|}{ Male } & \multicolumn{2}{|c|}{ Female } & \multirow{2}{*}{$\chi^{2}$} & \multirow{2}{*}{$\mathbf{P}$} \\
\hline & & & & & No. & $\begin{array}{c}\text { Per } \\
\text { cent. }\end{array}$ & No. & $\begin{array}{l}\text { Per } \\
\text { cent. }\end{array}$ & & & No. & $\begin{array}{c}\text { Per } \\
\text { cent. }\end{array}$ & No. & $\begin{array}{l}\text { Per } \\
\text { cent. }\end{array}$ & & \\
\hline \multirow[t]{2}{*}{ Age (yrs) } & \multicolumn{4}{|c|}{$\begin{array}{c}16-35 \\
36-45 \\
46-55 \\
56-65 \\
66 \text { and Over }\end{array}$} & $\begin{array}{r}26 \\
23 \\
27 \\
32 \\
9\end{array}$ & $\begin{array}{r}22 \cdot 2 \\
19.7 \\
23 \cdot 1 \\
27.2 \\
7.8\end{array}$ & $\begin{array}{l}13 \\
16 \\
21 \\
31 \\
12\end{array}$ & $\begin{array}{l}13 \cdot 9 \\
17 \cdot 2 \\
22 \cdot 6 \\
33 \cdot 3 \\
12 \cdot 9\end{array}$ & $\begin{array}{l}4 \cdot 131 \\
4 \text { d.f. }\end{array}$ & $\begin{array}{l}>\cdot 30 \\
\text { N.S. }\end{array}$ & $\begin{array}{l}10 \\
17 \\
22 \\
33 \\
10\end{array}$ & $\begin{array}{l}10 \cdot 8 \\
18 \cdot 4 \\
23.9 \\
35 \cdot 8 \\
10 \cdot 8\end{array}$ & $\begin{array}{l}29 \\
22 \\
26 \\
30 \\
11\end{array}$ & $\begin{array}{r}24 \cdot 6 \\
18 \cdot 6 \\
22 \cdot 0 \\
25 \cdot 4 \\
9 \cdot 3\end{array}$ & $\begin{array}{l}7 \cdot 340 \\
4 \text { d.f. }\end{array}$ & $\begin{array}{l}>\cdot 10 \\
\text { N.S. }\end{array}$ \\
\hline & Total & .. & $\ldots$ & . & 117 & 100 & 93 & 100 & & & 92 & 100 & 118 & 100 & & \\
\hline \multirow[t]{2}{*}{ Civil Status } & $\begin{array}{l}\text { Single } \\
\text { Married } \\
\text { Widowe } \\
\text { Divorce }\end{array}$ & $\begin{array}{l}\ddot{d} \\
\mathrm{~d}\end{array}$ & $\ddot{\xi}$ & $\therefore$ & $\begin{array}{l}16 \\
90 \\
11\end{array}$ & $\begin{array}{r}13.7 \\
76.9 \\
9.4\end{array}$ & $\begin{array}{r}8 \\
69 \\
16\end{array}$ & $\begin{array}{r}8 \cdot 6 \\
74 \cdot 1 \\
17 \cdot 2\end{array}$ & $\begin{array}{l}3 \cdot 592 \\
2 \text { d.f. }\end{array}$ & $\begin{array}{l}\text { P. } \cdot 10 \\
\text { N.S. }\end{array}$ & $\begin{array}{r}10 \\
73 \\
9\end{array}$ & $\begin{array}{r}10 \cdot 8 \\
79 \cdot 3 \\
9 \cdot 8\end{array}$ & $\begin{array}{l}14 \\
86 \\
18\end{array}$ & $\begin{array}{l}11 \cdot 9 \\
72.9 \\
15 \cdot 3\end{array}$ & $\begin{array}{l}1 \cdot 677 \\
2 \text { d.f. }\end{array}$ & $\begin{array}{l}\text { Z. } \cdot 20 \\
\text { N.S. }\end{array}$ \\
\hline & Total & . & $\cdots$ & . & 117 & 100 & 93 & 100 & & & 92 & 100 & 118 & 100 & & \\
\hline \multirow[t]{2}{*}{$\underset{\text { Class* }}{\text { Social }}$} & $\begin{array}{l}\text { I and II } \\
\text { III } \\
\text { IV and }\end{array}$ & & $\begin{array}{l}\ddot{ } \\
\cdots\end{array}$ & $\begin{array}{l}. \\
\cdots\end{array}$ & $\begin{array}{l}29 \\
52 \\
36\end{array}$ & $\begin{array}{l}24 \cdot 8 \\
44 \cdot 4 \\
30 \cdot 8\end{array}$ & $\begin{array}{l}25 \\
46 \\
22\end{array}$ & $\begin{array}{l}26 \cdot 8 \\
49 \cdot 4 \\
23 \cdot 6\end{array}$ & $\begin{array}{l}1 \cdot 328 \\
2 \text { d.f. }\end{array}$ & $\begin{array}{l}>\cdot 50 \\
\text { N.S. }\end{array}$ & $\begin{array}{l}22 \\
44 \\
26\end{array}$ & $\begin{array}{l}23 \cdot 9 \\
47 \cdot 8 \\
28 \cdot 2\end{array}$ & $\begin{array}{l}32 \\
54 \\
32\end{array}$ & \begin{tabular}{|l|}
$27 \cdot 1$ \\
$45 \cdot 8$ \\
$27 \cdot 1$
\end{tabular} & $\begin{array}{l}0 \cdot 292 \\
2 \text { d.f. }\end{array}$ & $\begin{array}{l}>\cdot 80 \\
\text { N.S. }\end{array}$ \\
\hline & Total & .. & .. & .. & 117 & 100 & 93 & 100 & & & 92 & 100 & 118 & 100 & & \\
\hline \multirow[t]{2}{*}{ Religiont } & $\begin{array}{l}\text { Protesta } \\
\text { Non-Pr }\end{array}$ & nt & $\therefore$ & $\begin{array}{l}. \\
.\end{array}$ & $\begin{array}{r}106 \\
11\end{array}$ & $\begin{array}{r}90 \cdot 5 \\
9 \cdot 5\end{array}$ & $\begin{array}{l}77 \\
16\end{array}$ & $\begin{array}{l}82 \cdot 7 \\
17 \cdot 3\end{array}$ & $\begin{array}{l}2 \cdot 755 \\
1 \text { d.f. }\end{array}$ & $\begin{array}{l}\text { >.05 } \\
\text { N.S. }\end{array}$ & $\begin{array}{r}83 \\
9\end{array}$ & $\begin{array}{r}90.2 \\
9.8\end{array}$ & $\begin{array}{r}100 \\
18\end{array}$ & \begin{tabular}{|l|}
$84 \cdot 7$ \\
$15 \cdot 3$
\end{tabular} & $\begin{array}{l}1 \cdot 354 \\
1 \text { d.f. }\end{array}$ & $\begin{array}{l}\text { >. } \\
\text { N.S. }\end{array}$ \\
\hline & Total & .. & . & .. & 117 & 100 & 93 & 100 & & & 92 & 100 & 118 & 100 & & \\
\hline
\end{tabular}

* As the numbers are small, Classes I and II, and IV and V have been combined.

t Apart from one Jewish patient, the religion was either Protestant or Roman Catholic.

TABLE VI

COMPARISON OF OUT-PATIENT SUB-GROUPS BY PARENTAL DEATH, OR PARENTAL ABSENCE FOR A PERIOD OF MORE THAN 3 MONTHS, BEFORE THE 16th BIRTHDAY

\begin{tabular}{|c|c|c|c|c|c|c|c|c|c|c|c|c|c|c|c|c|}
\hline \multirow{2}{*}{\multicolumn{2}{|c|}{ Out-patient Sub-groups }} & \multirow{3}{*}{.. } & \multirow{3}{*}{.. } & \multirow{3}{*}{.. } & \multicolumn{6}{|c|}{ Medical : Surgical } & \multicolumn{6}{|c|}{ Male : Female } \\
\hline & & & & & \multicolumn{2}{|c|}{ Medical } & \multicolumn{2}{|c|}{ Surgical } & \multirow{2}{*}{$x^{2}$} & \multirow{2}{*}{$\mathbf{P}$} & \multicolumn{2}{|c|}{ Male } & \multicolumn{2}{|c|}{ Female } & \multirow{2}{*}{$x^{2}$} & \multirow{2}{*}{$\mathbf{P}$} \\
\hline & & & & & No. & $\begin{array}{l}\text { Per } \\
\text { cent. }\end{array}$ & No. & $\begin{array}{l}\text { Per } \\
\text { cent. }\end{array}$ & & & No. & $\begin{array}{l}\text { Per } \\
\text { cent. }\end{array}$ & No. & $\begin{array}{l}\text { Per } \\
\text { cent. }\end{array}$ & & \\
\hline \multirow[t]{2}{*}{$\begin{array}{r}\text { Parent's } \\
\text { Death }\end{array}$} & $\begin{array}{l}\text { Died } \\
\text { Remain }\end{array}$ & $\mathrm{ed} \mathrm{Al}$ & & $\because$ & $\begin{array}{l}28 \\
89\end{array}$ & $\begin{array}{l}23 \cdot 9 \\
76 \cdot 1\end{array}$ & $\begin{array}{r}13 \\
80\end{array}$ & $\begin{array}{l}14.0 \\
86.0\end{array}$ & $\begin{array}{l}3 \cdot 320 \\
1 \text { d.f. }\end{array}$ & $\begin{array}{l}\text { Z.05 } \\
\text { N.S. }\end{array}$ & $\begin{array}{l}15 \\
77\end{array}$ & $\begin{array}{l}16 \cdot 3 \\
83.7\end{array}$ & $\begin{array}{l}26 \\
92\end{array}$ & $\begin{array}{l}22 \cdot 0 \\
78 \cdot 0\end{array}$ & $\begin{array}{l}1 \cdot 108 \\
1 \text { d.f. }\end{array}$ & $\begin{array}{l}\text { >. } \\
\text { N.S. }\end{array}$ \\
\hline & Total & . & .. & $\ldots$ & 117 & 100 & 93 & 100 & & & 92 & 100 & 118 & 100 & & \\
\hline \multirow{2}{*}{$\begin{array}{l}\text { Parent's } \\
\text { Absence } \\
\text { for } 3 \text { mths } \\
\text { or More }\end{array}$} & $\begin{array}{l}\text { Absent } \\
\text { Not Ab }\end{array}$ & sent & $\therefore$ & $\therefore$ & $\begin{array}{l}52 \\
65\end{array}$ & $\begin{array}{l}44.4 \\
55.6\end{array}$ & $\begin{array}{l}45 \\
48\end{array}$ & $\begin{array}{l}48 \cdot 4 \\
51 \cdot 6\end{array}$ & $\begin{array}{l}0.310 \\
1 \text { d.f. }\end{array}$ & $\begin{array}{l}\text { >.S.50 } \\
\text { N.S. }\end{array}$ & $\begin{array}{l}42 \\
50\end{array}$ & $\begin{array}{l}45 \cdot 7 \\
54 \cdot 3\end{array}$ & $\begin{array}{l}55 \\
63\end{array}$ & $\begin{array}{l}46 \cdot 6 \\
53 \cdot 4\end{array}$ & $\begin{array}{l}0.195 \\
1 \text { d.f. }\end{array}$ & $\begin{array}{l}\text { N.S. } 50 \\
\text { N.S. }\end{array}$ \\
\hline & Total & $\ldots$ & $\ldots$ & .. & 117 & 100 & 93 & 100 & & & 92 & 100 & 118 & 100 & & \\
\hline
\end{tabular}


TABLE VII

COMPARISON OF OUT-PATIENT SUB-GROUPS BY COMPLAINT OF A DISTURBED RELATIONSHIP WITH A PARENT DURING CHILDHOOD

\begin{tabular}{|c|c|c|c|c|c|c|c|c|c|c|c|}
\hline \multirow{3}{*}{ Out-patient Sub-groups } & \multirow{3}{*}{$\cdots$} & \multirow{3}{*}{$\cdots$} & \multirow{3}{*}{$\cdots$} & \multicolumn{4}{|c|}{ Medical : Surgical } & \multicolumn{4}{|c|}{ Male : Female } \\
\hline & & & & \multicolumn{2}{|c|}{ Medical } & \multicolumn{2}{|c|}{ Surgical } & \multicolumn{2}{|c|}{ Male } & \multicolumn{2}{|c|}{ Female } \\
\hline & & & & No. & Per cent. & No. & Per cent. & No. & Per cent. & No. & Per cent. \\
\hline \multirow{3}{*}{$\begin{array}{l}\text { Relationship } \\
\text { with Parent }\end{array}$} & \multicolumn{2}{|c|}{$\begin{array}{l}\text { Disturbed } \\
\text { Not Disturbed }\end{array}$} & $\begin{array}{l}\cdots \\
\cdots\end{array}$ & $\begin{array}{l}18 \\
99\end{array}$ & $\begin{array}{l}15 \cdot 4 \\
84 \cdot 6\end{array}$ & $\begin{array}{l}20 \\
73\end{array}$ & $\begin{array}{l}21 \cdot 5 \\
78 \cdot 5\end{array}$ & $\begin{array}{l}16 \\
76\end{array}$ & $\begin{array}{l}17 \cdot 4 \\
82 \cdot 6\end{array}$ & $\begin{array}{l}22 \\
96\end{array}$ & $\begin{array}{l}18 \cdot 6 \\
81 \cdot 4\end{array}$ \\
\hline & Total & . & $\cdots$ & 117 & 100 & 93 & 100 & 92 & 100 & 118 & 100 \\
\hline & & & & \multicolumn{4}{|c|}{$\chi^{2}=1 \cdot 334 ; 1$ d.f.; P> 10 N.S. } & \multicolumn{4}{|c|}{$\chi^{2}=0.048 ; 1$ d.f.; $P>\cdot 70$ N.S. } \\
\hline
\end{tabular}

It would therefore seem, in the light of the marked similarities between sub-groups, that the out-patients form a reasonably homogeneous sample, with no marked tendency to deviate along any of the measured parameters. Although the evidence is indirect, it is suggested that this is an indication that the out-patient sample is not unrepresentative of its parent population.

\section{Parental Bereavement in Childhood}

It is now possible to consider the main aim of the article: the frequency with which parental bereavement occurs in the childhood of a psychiatrically normal group. There is no reason to believe that the out-patients making up the sample have suffered from an excess of parental deprivation in childhood, except in the unlikely event that all four sub-groups suffered to the same excessive degree. Nor is there any indication that the subjects include an excess of individuals suffering from a condition thought to be particularly associated with parental deprivation; it will be remembered that twelve patients were excluded because of a possible history of affective disorder, and that none of the rest gave a history suggestive of other psychotic illness. Of the 210 outpatients only seven (3.3 per cent.) - all female-had had out-patient psychiatric treatment for psychoneurotic symptoms at some time in their lives. None had required in-patient psychiatric treatment and none exhibited psychiatric illness at interview. From the psychiatric standpoint, the out-patients seem to be a very normal group indeed.

\section{(1) Parental Death}

\section{Results}

Table VIII (col. a) (overleaf) shows the number of subjects who have lost one or other parent in childhood or early adult life. The number of parental deaths year by year till the 25th birthday is given, but it should be noted that the accompanying percentage figures are progressive, showing the proportion of the total who have lost a parent by any given birthday.

It can be seen that the annual parental mortality is fairly consistent and reaches a level of $19 \cdot 5$ per cent. at the 16th birthday, the upper limit of childhood in this investigation. Two subjects had lost both parents by death during childhood, but only the first death was included in this column. The parental mortality found in this study is rather higher than those found in the other studies quoted, possibly because a more careful inquiry was being made into the subject on this particular occasion.

Table VIII (cols $b$ and $c$ ) gives the figures for death of father and mother. As expected, paternal mortality is about twice as high as maternal mortality and this ratio remains fairly constant throughout childhood, adolescence, and early adult life.

The subjects range widely in age and it might be thought that the older members of the sample were more likely to have experienced the death of a parent during childhood since they were born into a world of higher mortality rates and earlier deaths. However, as Table IX (overleaf) shows, there is virtually no difference in this respect between those under 45 years of age (i.e. born after the first world war) and those aged 46 years and over.

Perhaps if it were possible to compare persons below 25 years of age with those above, the declining mortality rates of recent years might become apparent in reduced parental deaths in the childhood of the younger group. Unfortunately, the numbers in the present sample are not suitable for such a comparison.

\section{(2) Absence of a Parent for Any Cause during Childhood}

Subjects were asked about separation from their parents during childhood. A separation of 3 months or more, whatever the cause, was regarded as significant. Information on separation was obtained only for the duration of childhood; that is, up to the subject's 16 th birthday.

The period of 3 months was chosen because it 
TABLE VIII

AGE OF SUBJECT* AT TIME OF PARENT'S DEATH

\begin{tabular}{|c|c|c|c|c|c|c|}
\hline \multirow{2}{*}{$\begin{array}{l}\text { Age of } \\
\text { Subject } \\
\text { (yrs) }\end{array}$} & \multicolumn{2}{|c|}{ (a) } & \multicolumn{2}{|c|}{ (b) } & \multicolumn{2}{|c|}{ (c) } \\
\hline & $\begin{array}{l}\text { No. of Parents } \\
\text { dying within } \\
\text { the Year }\end{array}$ & $\begin{array}{l}\text { Per cent. of } \\
\text { Parents Dead }\end{array}$ & $\begin{array}{l}\text { No. of Fathers } \\
\text { dying within } \\
\text { the Year }\end{array}$ & $\begin{array}{l}\text { Per cent. of } \\
\text { Fathers Dead }\end{array}$ & $\begin{array}{l}\text { No. of Mothers } \\
\text { dying within } \\
\text { the Year }\end{array}$ & $\begin{array}{l}\text { Per cent. of } \\
\text { Mothers Dead }\end{array}$ \\
\hline $\begin{array}{l}0-1 \\
1-2 \\
2-3 \\
3-4 \\
4-5\end{array}$ & $\begin{array}{l}3 \\
2 \\
4 \\
3 \\
6\end{array}$ & $\begin{array}{l}1 \cdot 4 \\
2 \cdot 4 \\
4 \cdot 3 \\
5 \cdot 7 \\
8 \cdot 6\end{array}$ & $\begin{array}{l}1 \\
2 \\
2 \\
1 \\
6\end{array}$ & $\begin{array}{l}0 \cdot 5 \\
1 \cdot 4 \\
2 \cdot 4 \\
2 \cdot 9 \\
5 \cdot 7\end{array}$ & $\begin{array}{l}2 \\
0 \\
2 \\
2 \\
1\end{array}$ & $\begin{array}{l}1 \cdot 0 \\
1.0 \\
1.9 \\
2.9 \\
3 \cdot 3\end{array}$ \\
\hline $\begin{array}{l}5-6 \\
6-7 \\
7-8 \\
8-9 \\
9-10\end{array}$ & $\begin{array}{l}3 \\
2 \\
4 \\
1 \\
3\end{array}$ & $\begin{array}{l}10 \cdot 0 \\
11.0 \\
12.9 \\
13 \cdot 3 \\
14.8\end{array}$ & $\begin{array}{l}3 \\
2 \\
2 \\
1 \\
1\end{array}$ & $\begin{array}{r}7 \cdot 1 \\
8 \cdot 1 \\
9 \cdot 1 \\
9 \cdot 5 \\
10 \cdot 0\end{array}$ & $\begin{array}{l}\mathbf{0} \\
\mathbf{0} \\
\mathbf{2} \\
\mathbf{0} \\
\mathbf{2}\end{array}$ & $\begin{array}{l}3 \cdot 3 \\
3 \cdot 3 \\
4 \cdot 3 \\
4 \cdot 3 \\
5 \cdot 2\end{array}$ \\
\hline $\begin{array}{l}10-11 \\
11-12 \\
12-13 \\
13-14 \\
14-15\end{array}$ & $\begin{array}{l}0 \\
2 \\
3 \\
2 \\
3\end{array}$ & $\begin{array}{l}14 \cdot 8 \\
15 \cdot 7 \\
17 \cdot 1 \\
18 \cdot 1 \\
19 \cdot 5\end{array}$ & $\begin{array}{l}0 \\
2 \\
1 \\
1 \\
1\end{array}$ & $\begin{array}{l}10.0 \\
11.0 \\
11.4 \\
11.9 \\
12.4\end{array}$ & $\begin{array}{l}0 \\
0 \\
2 \\
2 \\
2\end{array}$ & $\begin{array}{l}5 \cdot 2 \\
5 \cdot 2 \\
6 \cdot 2 \\
7 \cdot 1 \\
8 \cdot 1\end{array}$ \\
\hline $\begin{array}{l}15-16 \\
16-17 \\
17-18 \\
18-19 \\
19-20\end{array}$ & $\begin{array}{l}0 \\
3 \\
2 \\
3 \\
4\end{array}$ & $\begin{array}{l}19 \cdot 5 \\
21 \cdot 1 \\
22 \cdot 1 \\
23 \cdot 7 \\
25 \cdot 6\end{array}$ & $\begin{array}{l}\mathbf{0} \\
\mathbf{2} \\
\mathbf{2} \\
\mathbf{3} \\
\mathbf{3}\end{array}$ & $\begin{array}{l}12 \cdot 4 \\
13 \cdot 5 \\
14 \cdot 4 \\
15 \cdot 8 \\
17 \cdot 4\end{array}$ & $\begin{array}{l}0 \\
2 \\
0 \\
0 \\
1\end{array}$ & $\begin{array}{l}8 \cdot 1 \\
9 \cdot 1 \\
9 \cdot 1 \\
9 \cdot 1 \\
9 \cdot 7\end{array}$ \\
\hline $\begin{array}{l}20-21 \\
21-22 \\
22-23 \\
23-24 \\
24-25\end{array}$ & $\begin{array}{l}1 \\
1 \\
3 \\
7 \\
4\end{array}$ & $\begin{array}{l}26 \cdot 6 \\
27 \cdot 4 \\
29 \cdot 0 \\
32 \cdot 6 \\
34 \cdot 2\end{array}$ & $\begin{array}{l}2 \\
2 \\
2 \\
5 \\
4\end{array}$ & $\begin{array}{l}18 \cdot 7 \\
19 \cdot 7 \\
21 \cdot 0 \\
23 \cdot 6 \\
25 \cdot 6\end{array}$ & $\begin{array}{l}\mathbf{0} \\
0 \\
1 \\
4 \\
1\end{array}$ & $\begin{array}{r}9 \cdot 9 \\
10 \cdot 0 \\
10 \cdot 5 \\
12 \cdot 5 \\
13 \cdot 1\end{array}$ \\
\hline
\end{tabular}

- From age 16 onwards, the percentage figures are corrected for individuals who have not yet reached the age denoted.

TABLE IX

COMPARISON OF SUBJECTS ABOVE AND BELOW THE AGE OF 45 YEARS BY FREQUENCY OF PARENTAL DEATH BEFORE THE 16th BIRTHDAY

\begin{tabular}{|c|c|c|c|c|c|c|c|c|c|c|c|c|}
\hline \multirow{2}{*}{\multicolumn{2}{|c|}{ Age of Subject (yrs) }} & \multirow{2}{*}{$\cdots$} & \multirow{2}{*}{$\cdots$} & \multirow{2}{*}{. } & \multirow{2}{*}{$\cdots$} & \multirow{2}{*}{$\cdots$} & \multirow{2}{*}{. } & \multirow{2}{*}{$\cdots$} & \multicolumn{2}{|c|}{ Over 45} & \multicolumn{2}{|c|}{ Below 45} \\
\hline & & & & & & & & & $\begin{array}{l}\text { No. of } \\
\text { Subjects }\end{array}$ & $\begin{array}{l}\text { Per cent. of } \\
\text { Total Subjects }\end{array}$ & $\begin{array}{l}\text { No. of } \\
\text { Subjects }\end{array}$ & $\begin{array}{l}\text { Per cent. of } \\
\text { Total Subjects }\end{array}$ \\
\hline \multirow[t]{2}{*}{ Parent } & \multicolumn{5}{|c|}{$\begin{array}{l}\text { Died in Subject's Childhood } \\
\text { Alive throughout Childhood }\end{array}$} & . & . & 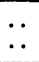 & $\begin{array}{l}15 \\
63\end{array}$ & $\begin{array}{l}23 \cdot 8 \\
76 \cdot 2\end{array}$ & $\begin{array}{r}26 \\
106\end{array}$ & $\begin{array}{l}24 \cdot 5 \\
75 \cdot 5\end{array}$ \\
\hline & Tota & & $\cdots$ & $\cdots$ & $\cdots$ & $\cdots$ & $\cdots$ & $\cdots$ & 78 & 100 & 132 & 100 \\
\hline
\end{tabular}

seemed sufficiently long to be capable of causing a sense of bereavement in the child and also long enough to remain memorable into adult life. Many subjects were unsure of the duration of the separation but if they thought it had lasted less than 3 months it was not included. In some cases, absences occurred more than once, but these have not been differentiated. All forms of separation were considered, including absence of the child from the parental home (e.g. for hospitalization) as well as absence of a parent.

Table X (col.a) (opposite) shows absence of parents for any cause other than death; almost one-third of the sample admitted to such an absence. Much of this total is accounted for by paternal absences which outnumber maternal absences by about three to one. Only 6.7 per cent. had suffered temporary absences of both parents.
Table X (col. b) displays the combined total of subjects who have suffered from any form of parental bereavement, including death. Almost half of the entire sample have had a childhood bereavement experience in relation to the parents, again largely due to paternal absence and death. 11.9 per cent. of the total had suffered some form of bereavement from both parents. These figures are very much higher than previous studies suggest.

A sizeable proportion of the paternal absences were due to wartime service in the armed forces. Lest it be thought that this is too universal an occurrence to be regarded as a bereavement experience, Table $\mathrm{XA}$ (opposite) re-enumerates the details of Table $\mathrm{X}$, but omitting paternal absences due solely to wartime military service. The number of subjects who have suffered parental loss has fallen considerably but still amounts to one-third of the total. 
TABLE X

LOSS OF A PARENT BEFORE THE 16th BIRTHDAY

\begin{tabular}{|c|c|c|c|c|c|c|c|c|c|c|c|}
\hline \multirow{2}{*}{\multicolumn{2}{|c|}{ Cause of Parental Loss }} & \multirow{2}{*}{$\cdots$} & \multirow{2}{*}{$\cdots$} & \multirow{2}{*}{$\cdots$} & \multirow{2}{*}{$\cdots$} & \multirow{2}{*}{$\cdots$} & \multirow{2}{*}{$\cdots$} & \multicolumn{2}{|c|}{$\begin{array}{c}(a) \\
\text { Any Cause Other than Death }\end{array}$} & \multicolumn{2}{|c|}{ Any Cause including Death } \\
\hline & & & & & & & & $\begin{array}{l}\text { No. of Subjects } \\
\text { losing a Parent }\end{array}$ & $\begin{array}{l}\text { Per cent. of } \\
\text { Total Subjects }\end{array}$ & $\begin{array}{l}\text { No. of Subjects } \\
\text { losing a Parent }\end{array}$ & $\begin{array}{l}\text { Per cent. of } \\
\text { Total Subjects }\end{array}$ \\
\hline Parent Lost & $\begin{array}{l}\text { Either } \\
\text { Father } \\
\text { Mother } \\
\text { Both }\end{array}$ & $\begin{array}{l}\cdots \\
\ddot{*} \\
\cdots\end{array}$ & $\begin{array}{l}\cdots \\
\ddot{*} \\
\cdots\end{array}$ & $\begin{array}{l}\cdots \\
\ddot{*} \\
\cdots\end{array}$ & $\begin{array}{l}\cdots \\
\cdots \\
\cdots\end{array}$ & $\begin{array}{l}\ddot{ } \\
\ddot{*}\end{array}$ & $\begin{array}{l}\cdots \\
\cdots \\
\cdots\end{array}$ & $\begin{array}{l}68 \\
61 \\
19 \\
14\end{array}$ & $\begin{array}{r}32.4 \\
29.0 \\
9 \cdot 1 \\
6.7\end{array}$ & $\begin{array}{l}98 \\
87 \\
36 \\
25\end{array}$ & $\begin{array}{l}46 \cdot 7 \\
41 \cdot 4 \\
17 \cdot 2 \\
11 \cdot 9\end{array}$ \\
\hline
\end{tabular}

TABLE X $A$

AS TABLE X BUT EXCLUDING TEMPORARY ABSENCES OF FATHER DUE SOLELY TO WARTIME SERVICE IN THE ARMED FORCES

\begin{tabular}{|c|c|c|c|c|c|c|c|c|c|c|c|}
\hline \multirow{2}{*}{\multicolumn{2}{|c|}{ Cause of Parental Loss }} & \multirow{2}{*}{$\cdots$} & \multirow{2}{*}{$\cdots$} & \multirow{2}{*}{$\cdots$} & \multirow{2}{*}{$\cdots$} & \multirow{2}{*}{$\cdots$} & \multirow{2}{*}{$\cdots$} & \multicolumn{2}{|c|}{$\begin{array}{l}(a) \\
\text { Any Cause Other than Death }\end{array}$} & \multicolumn{2}{|c|}{$\begin{array}{c}\text { Any Cause Other than Wartime } \\
\text { Service }\end{array}$} \\
\hline & & & & & & & & & & & \\
\hline Parent Lost & $\begin{array}{l}\text { Either } \\
\text { Father } \\
\text { Mother } \\
\text { Both }\end{array}$ & $\begin{array}{l}\cdots \\
\cdots \\
\cdots\end{array}$ & $\begin{array}{l}\cdots \\
\ddot{*} \\
\cdots\end{array}$ & $\begin{array}{l}\cdots \\
\cdots \\
\cdots\end{array}$ & $\begin{array}{l}\ddot{ } \\
\ddot{*}\end{array}$ & $\begin{array}{l}\ddot{*} \\
\ddot{*} \\
\cdots\end{array}$ & $\begin{array}{l}\cdots \\
\ddot{\cdots} \\
\cdots\end{array}$ & $\begin{array}{l}40 \\
37 \\
19 \\
10\end{array}$ & $\begin{array}{r}19 \cdot 1 \\
17 \cdot 6 \\
9 \cdot 1 \\
4 \cdot 8\end{array}$ & $\begin{array}{l}70 \\
63 \\
36 \\
18\end{array}$ & $\begin{array}{r}33 \cdot 3 \\
30 \cdot 0 \\
17 \cdot 2 \\
8 \cdot 6\end{array}$ \\
\hline
\end{tabular}

(3) Loss of a Parent associated with Emotional Trauma

In the majority of cases, subjects reported the absence or loss of a parent quite dispassionately, repression or passage of time having eradicated conscious memories of any emotional disturbance they may have suffered at the time. However, a proportion did admit to emotional trauma associated with bereavement and these are reported in Table XI.

TABLE XI

LOSS OF A PARENT FOR ANY CAUSE DURING CHILDHOOD WHICH THE SUBJECT REPORTED AS HAVING BEEN EMOTIONALLY DISTURBING

\begin{tabular}{|c|c|c|c|c|}
\hline \multicolumn{3}{|c|}{ Parent Lost } & No. of Subjects & Per cent. of \\
\hline $\begin{array}{l}\text { Either .. } \\
\text { Father .. } \\
\text { Mother } \\
\text { Both .. }\end{array}$ & & $\begin{array}{l}\because \\
\because \\
\cdots\end{array}$ & $\begin{array}{r}25 \\
20 \\
11 \\
6\end{array}$ & $\begin{array}{r}11 \cdot 9 \\
9.5 \\
5.2 \\
2.9\end{array}$ \\
\hline
\end{tabular}

If these figures are compared with the absolute figures for parent-child separation (Table X, col. $b$ ), it will be noted that only about one-quarter of the patients reporting parental bereavement regarded it as having been distressing at the time. It is not suggested that this represents anything like an accurate picture of the child's reaction to bereavement, since the subject's accounts are distorted by time and personal judgement. Nevertheless, it is quite striking that 11.9 per cent. of the members of a psychiatrically normal group should recall a distressing separation experience in childhood.

\section{(4) Reports by Subjects of a Disturbed Relationship with a Parent during Childhood}

As a corollary to emotional disturbance in relation to parent-loss, it is perhaps apposite to mention disturbed parent-child relationship, about which each subject was asked. This, of course, need not be associated with bereavement, but frequently is so in this series. Table XII shows the proportions of those who complained of a disturbed relationship.

TABLE XII

REPORT BY THE SUBJECT OF A DISTURBED RELATIONSHIP WITH A PARENT DURING CHILDHOOD

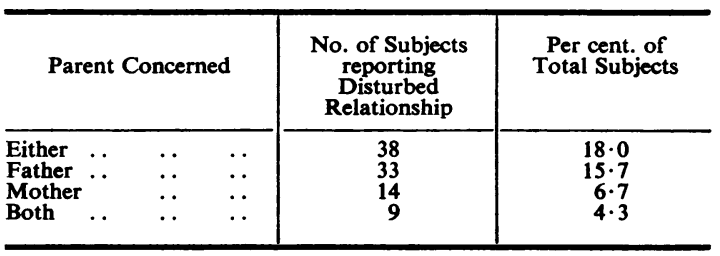

In all, 18 per cent. of the subjects reported a marked disturbance of relationship with a parent or parent-figure at some time in childhood. If the integrity of the parent-child relationship is vital to the normal emotional development of the child, this seems a remarkably high percentage for a group of persons who do not appear especially prone to psychiatric illness. 


\section{Discussion}

This article is not primarily concerned with theoretical aspects of parental bereavement in childhood. Rather, it is an attempt to provide some basic statistics in an aspect of psychiatry where speculation is rampant but facts few-in particular, to demonstrate with what frequency parental loss may be expected to occur during the childhood of normal individuals.

The only truly satisfactory method of studying the incidence and the effects of parental bereavement is to observe its occurrence and its aftermath under carefully controlled circumstances. Since this is extremely difficult to arrange, the retrospective type of study is generally employed. Usually this seeks to demonstrate the importance of parent loss in predisposing individuals to some mental illness, but if the study is to achieve this aim it is obvious that it will either have to show that bereavement in the mentally-ill group occurs significantly more often than the very high numbers obtained in the present study or else that the circumstances of bereavement are qualitatively different. Even if it does show that there is a significant relationship between the bereavement and the illness, it need not necessarily be true to say that this relationship is an aetiological one.

It would be appropriate here to make a strong plea that any study in this subject should define its terms clearly, adopt definitions which can be widely accepted, and use objective methods of assessment. Also, it is desirable that investigators be aware that levels of parental bereavement in childhood may normally vary widely according to different circumstances, which serves to emphasize the outstanding need for satisfactory control methods.

If the results of this study are typical, then the amount of child-parent separation which takes place in a community is enormous. We tend to believe that it is only a few unlucky children who lose their parents for any length of time but, in fact, almost half the subjects in this study experienced separation from one or other parent for at least 3 months before the 16th birthday. Of the total sample, $19 \cdot 5$ per cent. had lost a parent by death by the 16th birthday. Yet these people are probably at least as normal in the psychiatric sense as any group taken from the general population, and there is evidence to suggest that they have not been excessively prone to parentloss. Moreover, the sample is taken from an essentially stable, homogeneous community, and the members of the sample themselves show evidence of considerable social stability. For example, only two ( 0.9 per cent.) of the 210 out-patients are divorced or separated from their spouses. This all tends to suggest that childhood parental bereavement is a very common phenomenon indeed. In all aspects of bereavement, the father is invariably absent much more frequently than the mother, even when absences due solely to wartime service in the armed forces are excluded.

It may be that to measure the amount of parentchild separation gives a misleading picture, but it would certainly seem to indicate that bereavement cannot be per se a potent predisposing factor in mental illness; otherwise one would scarcely expect the subjects of this study to be so normal psychiatrically. Even when one considers the quality of the bereavement experience by asking the subject to state whether he was distressed at the time, 11.9 per cent. of the sample admitted that it caused considerable emotional trauma. Although this is only a quarter of the number who suffered parental bereavement, it is still quite a sizeable proportion of the total sample. It is interesting to note that father continues to maintain his lead in this traumatic bereavement group, which certainly does not suggest that it is loss of mother which is perceived by the individual as being of overwhelming importance.

Parental bereavement must obviously have some psychological effect on the child and sometimes this effect may be overwhelming, either because the child is predisposed in some way or because the circumstances of the bereavement are catastrophic. However, it appears that it is such a common experience that it cannot per se have the aetiological significance in mental illness so often assigned to it. Many previous studies have given misleading results because of faulty experimental methods and there is a great need for carefully designed and closely controlled investigations in the field of childhood parent loss.

Finally, it is suggested that, as employed in this investigation, a group of medical and surgical outpatients are eminently suitable to act as control subjects in this type of psychiatric investigation.

\section{SUMmary}

210 medical and surgical out-patients were interviewed by the author to obtain information on childhood parental bereavement in psychiatrically normal individuals. At the time of interview, none of the outpatients was suffering from a condition thought to be associated with parental deprivation. Data are presented which suggest that the out-patients are a homogeneous group, probably not unrepresentative of the general population, and that they are an appropriate source of normal material. 
The following results were obtained:

(1) $19 \cdot 5$ per cent. of the subjects had lost a parent by death before the 16th birthday. This figure rises to $34 \cdot 2$ per cent. by the 25 th birthday. The corresponding figures for loss of father by death are 12.4 and 25.6 per cent. and for loss of mother $8 \cdot 1$ and $13 \cdot 1$ per cent.

(2) 32.4 per cent. reported that they had been separated from a parent for at least 3 months during childhood for a cause other than death (father 29 per cent., mother $9 \cdot 1$ per cent., both parents 6.7 per cent.).

(3) When all causes of separation including death are considered, 46.7 per cent. of the subjects had undergone parental bereavement in childhood as defined in this study $(41.4$ per cent. separated from father, 17.2 per cent. from mother, 11.9 per cent from both parents).

(4) When the subjects were asked to state if the loss had been emotionally disturbing to them at the time, 11.9 per cent. reported having been distressed at the loss of a parent $(9 \cdot 5$ per cent. at loss of father, $5 \cdot 2$ per cent. at loss of mother, 2.9 per cent. at loss of both parents).

(5) Enquiry was made into disturbed relationship with a parent figure during childhood, not necessarily associated with bereavement; 18.0 per cent. reported such a disturbance $(15.7$ per cent. with father, $6 \cdot 7$ per cent. with mother, and 4.3 per cent. with both parents).

The findings suggest that children experience parental bereavement much more commonly than is generally realized. This being so, it is difficult to accept that parental bereavement per se can be an important predisposing factor in mental illness.

The need for further studies is discussed.

I wish to thank Prof. G. M. Carstairs and Dr W. I. N. Kessel for their advice in the planning and carrying out of this study. I am extremely grateful to the physicians and surgeons of the Western General Hospital, Edinburgh, and especially to Dr J. A. Strong, for permission to interview out-patients and for their enthusiastic help.

The study was carried out while the author was a clinical member of the scientific staff of the Medical
Research Council Unit for Research on the Epidemiology of Psychiatric Illness, 2 George Square, Edinburgh 8.

\section{REFERENCES}

Barry, H., Jr., and Lindemann, E. (1960. Psychosom. Med., 22, 166.

Batchelor, I. R. C., and Napier, M. B. (1953). Brit. J. Delinq., 4, 99.

Beck, A. T., Sethi, B. B., and Tuthill, R. W. (1963). Arch. gen. Psychiat., 9, 295.

Bowlby, J. (1940). Int. J. Psycho-Anal., 21, 154. (1944). Ibid.. 25, 107.

(1962). In "Aspects of Psychiatric Research", ed. D. Richter, J. M. Tanner, Lord Taylor, and O. L. Zangwill, p. 262. Oxford University Press, London.

Brown, F. (1961). J. ment. Sci., 107, 754.

Casler, L. (1961). "Maternal Deprivation: a critical review of the literature." Monogr. Soc. Res. Child Develop., 26, no. 2.

Earle, A. M., and Earle, B. V. (1961). Amer. J. Orthopsychiat., 31, 181.

Gregory, I. (1958). Amer. J. Psychiat., 115, 432.

Hilgard, J. R., and Newman, M. F. (1963). J. nerv. ment. Dis., 137, 14.

,,$\frac{13}{788}$, and Fisk, F. (1960). Amer. J. Orthopsychiat., 30, 788

Imboden, J. B., Canter, A., and Cluff, L. (1963). Psychosom. Med., 25, 433.

Ingham, H. V. (1949). Amer. J. Psychiat., 106, 91.

Lidz, R. W., and Lidz, T. (1949). Ibid., 106, 332.

Madow, L., and Hardy, S. E. (1947). Amer. J. Orthopsychiat., 17, 521.

Metropolitan Life Insurance Co. (1944). Statistical Bulletin, 25 , no. 3 , p. 3.

Norton, A. (1952). Brit. J. soc. Med., 6, 253.

Oltman, J. E., McGarry, J. J., and Friedman, S. (1951). Amer. J. Psychiat., 108, 685.

Palmer, D. M. (1941). J. nerv. ment. Dis., 93, 421.

Reitman, F. (1942). J. ment. Sci., 88, 580.

Rheingold, H. L. (1956). "The Modification of Social Responsiveness in Institutional Babies." Monogr. Soc. Res. Child Develop., 21, no. 2.

and Bayley, N. (1959. Monogr. Soc. Res. Child Develop., 30, 363.

Ribble, M. A. (1943). "The Rights of Infants: Early Psychological Needs and their Satisfaction." Columbia University Press, New York.

Robins, E., Schmidt, E. H., and O'Neal, P. (1957). Amer. J. Psychiat., 114, 221.

Simon, W. (1950). J. nerv. ment. Dis., 111, 451.

Spitz, R. A. (1945). Psychoanal. Stud. Child, 1, 53.

Stein, L., and Sklaroff, S. A. (1957). "Stages of family growth." Paper read at the Royal Statistical Society, London (unpublished).

Stengel, E. (1943). J. ment. Sci., 89, 224.

Swaroop, S. (1960). "Introduction to Health Statistics." Livingstone, Edinburgh.

Wahl, C. W. (1956). Amer. J. Psychiat., 113, 201. 